\title{
Reproductive aspects of naleh fish (Barbonymus sp.): A native species from Nagan river, Aceh Province, Indonesia
}

\author{
DENI EFIZON ${ }^{1 \bullet}$, AGUNG S. BATUBARA ${ }^{2}$, ZAINAL A. MUCHLISIN ${ }^{3}$, ROZA ELVYRA $^{4}$, SYAMSUL RIZAL $^{5}$, \\ MOHD M. SITI-AZIZAH ${ }^{6}$ \\ ${ }^{1}$ Faculty of Fisheries and Marine Sciences, Universitas Riau. Kampus Bina Widya, Jl. HR. Subrantas Km. 12,5, Simpang Baru, Pekanbaru 28293, Riau, \\ Indonesia. Tel.: +62-761-63275, Fax.: +62-761-63275, •email: deni.efizon@lecturer.unri.ac.id \\ ${ }^{2}$ Faculty of Mathematics and Natural Sciences, Universitas Negeri Medan. Jl. Willem Iskandar, Pasar V, Medan 20221, North Sumatra, Indonesia \\ ${ }^{3}$ Department of Aquaculture, Faculty of Marine and Fisheries, Universitas Syiah Kuala. J1. Putroe Phang, Darussalam, Banda Aceh 23111, Aceh, \\ Indonesia \\ ${ }^{4}$ Department of Biology, Faculty of Mathematics and Natural Sciences, Universitas Riau. Kampus Bina Widya, Jl. HR. Subrantas Km. 12,5, Simpang \\ Baru, Pekanbaru 28293, Riau, Indonesia. \\ ${ }_{5}^{5}$ Department of Marine Sciences, Faculty of Marine and Fisheries, Universitas Syiah Kuala. Jl. Putroe Phang Darussalam, Banda Aceh 23111, Aceh, \\ Indonesia \\ ${ }^{6}$ Institute Marine Biotechnology, University of Malaysia Terengganu. Kuala Terengganu 21300, Terengganu, Malaysia
}

Manuscript received: 20 November 2020. Revision accepted: 20 April 2021.

\begin{abstract}
Efizon D, Batubara AS, Muchlisin ZA, Elvyra R, Rizal S, Siti-azizah MM. 2021. Reproductive aspects of naleh fish (Barbonymus sp.): A native species from Nagan river, Aceh Province, Indonesia. Biodiversitas 22: 2682-2690. Naleh fish (Barbonymus sp.) is a native species in Indonesia and reproductive biology is key information to planning a better conservation strategy for this species. Hence, the present study aimed to examine the spawning season, sex ratio, and fecundity of the naleh fish harvested from Nagan Raya District, Aceh Province, Indonesia. Sampling was conducted from January to December 2016 at three sampling locations that were determined purposively based on the recommendations of local fishermen. The fish samples were caught using casting nets and gillnets at two-week intervals. A total of 761 fish samples, comprising 135 females and 626 males, with males predominating at a ratio of 1:4.6 (female: male). The gonadosomatic index (GSI) average of the females ranged from $0.58 \%$ to $4.28 \%$, while $1.24 \%$ to $4.18 \%$ for males. The male fish first matured at $73 \mathrm{~mm}$, whereas the female reached maturity at a size of $85 \mathrm{~mm}$. The total fecundity ranged from 6565725 eggs with an average of 2663.2 eggs, whereas the relative fecundity from 35.69-254.65 eggs gram ${ }^{-1}$ body weight with an average

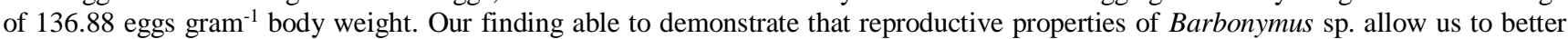
estimate their spawning season either females and males, which can be useful for conservation planning and also their fecundity data was important for aquaculture development in the future.
\end{abstract}

Keywords: Barbonymus, fecundity, naleh, reproductive, spawning season

\section{INTRODUCTION}

Barbonymus is a true freshwater fish distributed widely in Southeast Asia countries, including Indonesia, Malaysia, Thailand, Vietnam, and the Philippines (Kottelat 2001; Cheng et al. 2004; Satrawaha and Pilasamorn 2009). Ten species of Barbonymus have been described worldwide (Yang et al. 2012; Zheng et al. 2016; Froese and Pauly 2018). This organism is a commercial freshwater fish and shows promise for aquaculture (Muchlisin 2013) and has been introduced to several countries, such as India, Pakistan, Bangladesh, and Spain (Mondol et al. 2005; Gante et al. 2008; Leunda 2010; Mollah et al. 2011; Hossain et al. 2016). In Aceh Province, Indonesia, two species of Barbonymus have been recorded, namely, Barbonymus schwanenfeldii (locally known as Lampam) and Barbonymus sp. (with a local name of naleh) (Batubara et al. 2018). Lampan fish is distributed within the eastern and central parts of Aceh Province, whereas the naleh fish is only found in the western and southern parts of the region (Muchlisin and Siti-Azizah 2009; Muchlisin et al. 2015). A previous study showed that naleh fish is genetically distant from other Barbonymus species that have been deposited in the Genbank and is therefore presumed a cryptic species (Batubara et al. 2021, pers. comm).

The lampan fish B. schwanenfeldii has been intensively studied by researchers in various aspects, for example, bioecology (Gante et al. 2008; Dewantoro 2015; Huwoyon and Kusmini 2017; Sabarudin et al. 2017; Apendi et al. 2018; Nyanti et al. 2018), genetics (Kamarudin and Esa 2009; Kusmini et al. 2017a; Radona et al. 2017), fish nutrition and immunology (Eslamloo et al. 2012; Song et al. 2012; Eslamloo et al. 2013; Zhu et al. 2016; Eslamloo et al. 2017; Idris et al. 2017; Nyanti et al. 2017; Huwoyon et al. 2018), pathology (Székely et al. 2009; Abdullah et al. 2018), and population dynamics (Isa et al. 2012). However, the reports on naleh fish as cryptic species in Nagan river are very limited.

To date, only four studies have been reported about naleh fish, and they mainly focused on morphological variations (Batubara et al. 2018), length-weight relations and condition factors (Batubara et al. 2019a), population dynamics (Batubara et al. 2019b), and genetics (Batubara et 
al. 2021, pers. comm); meanwhile, the biological aspects of naleh fish has never been studied. This fish has been intensively harvested and subjected to (Batubara et al. $2019 \mathrm{~b}$ ), and therefore, conservation action is extremely crucial. According to the studies of Cnaani and Sivan (2009) and Muchlisin et al. (2010), information on the reproductive biology of fish is useful for developing an artificial breeding technology. The data on reproductive biology are also crucial to plan for better fisheries management strategy (Chew and Zulkafli 2012; Hossen et al. 2017). Barbieri et al. (2011) stated that the data on reproductive aspects is an essential reference to determine the reproductive ability of fish and population dynamics. Hence, the present study aimed to analyze several reproductive biological aspects of the naleh fish as cryptic species in Nagan river, Aceh Province, Indonesia.

\section{MATERIALS AND METHODS}

\section{Time and site}

Sampling was conducted from January to December 2016 at the Nagan river, Nagan Raya District, Aceh Province, Indonesia. The samples were processed and analyzed in the Laboratory of Ichthyology, Faculty of Marine and Fisheries, Universitas Syiah Kuala in Banda Aceh, Indonesia.

\section{Sampling procedure}

Sampling was performed twice per month (two-week interval) for 12 months at three sampling sites along Nagan river. The sampling sites were determined purposively based on information on locations where naleh fish are often caught as mentioned by local fishermen: (i) Babah
Krueng Village $\left(4^{\circ} 16^{\prime} 25.25^{\prime \prime} \mathrm{N}\right.$; 96 $\left.24^{\circ} 22.34^{\prime \prime} \mathrm{E}\right)$; (ii) Blang Mesjid Village $\left(4^{\circ} 17^{\prime} 4.73^{\prime \prime} \mathrm{N}\right.$; $\left.96^{\circ} 25^{\prime} 56.83^{\prime \prime} \mathrm{E}\right)$; and (iii) Pante Ara Village ( $\left.4^{\circ} 16^{\prime} 48.49^{\prime \prime} \mathrm{N} ; 9^{\circ} 27^{\prime} 8.50^{\prime \prime} \mathrm{E}\right)$ (Figure 1).

The fish were sampled using gillnets, casting nets, and handline hooks from 08.00 AM to 16.00 PM. The sampled fish were washed, and the total body weight $(\mathrm{g})$ and total length $(\mathrm{mm})$ were measured using a digital balance (Toledo, AB-204, standard error $=0.01 \mathrm{~g}$ ) and digital calipers (Mitutoyo, CD-6CS, standard error $=0.01 \mathrm{~mm}$ ), respectively. The representative fish were photographed for documentation, preserved in $10 \%$ formalin, and then transported to the laboratory in Universitas Syiah Kuala, Banda Aceh for further analysis. The research was followed for the care and use of animals during the research (Section of Animal Care and Use in Research. Chapter 6, Article 11-13) (https://lppm.unsyiah.ac.id/files/ Etika-Penelitian-Unsyiah.pdf).

\section{Gonad maturity stage and gonadosomatic index (GSI) analyses}

The fish samples were anesthetized and overdosed using oil clove, weighed, and measured (total length, $\mathrm{mm}$ ). Then, the fish were sacrificed by abdominal section. The gonads were removed and cleaned using tissue paper. The gonads were weighed and observed for various characteristics (morphology, color, surface texture, and the presence of milt or oocytes). The fish were grouped into five stages of gonad maturity following the work of Haryono et al. (2015). The classification was developed by Haryono et al. (2015) for $B$. balleroides, a relative of naleh fish. The GSI was calculated based on the work of Muchlisin et al. (2010) as follows: GSI $(\%)=$ gonad weight (g)/ Total body weight $(\mathrm{g})$ x 100.

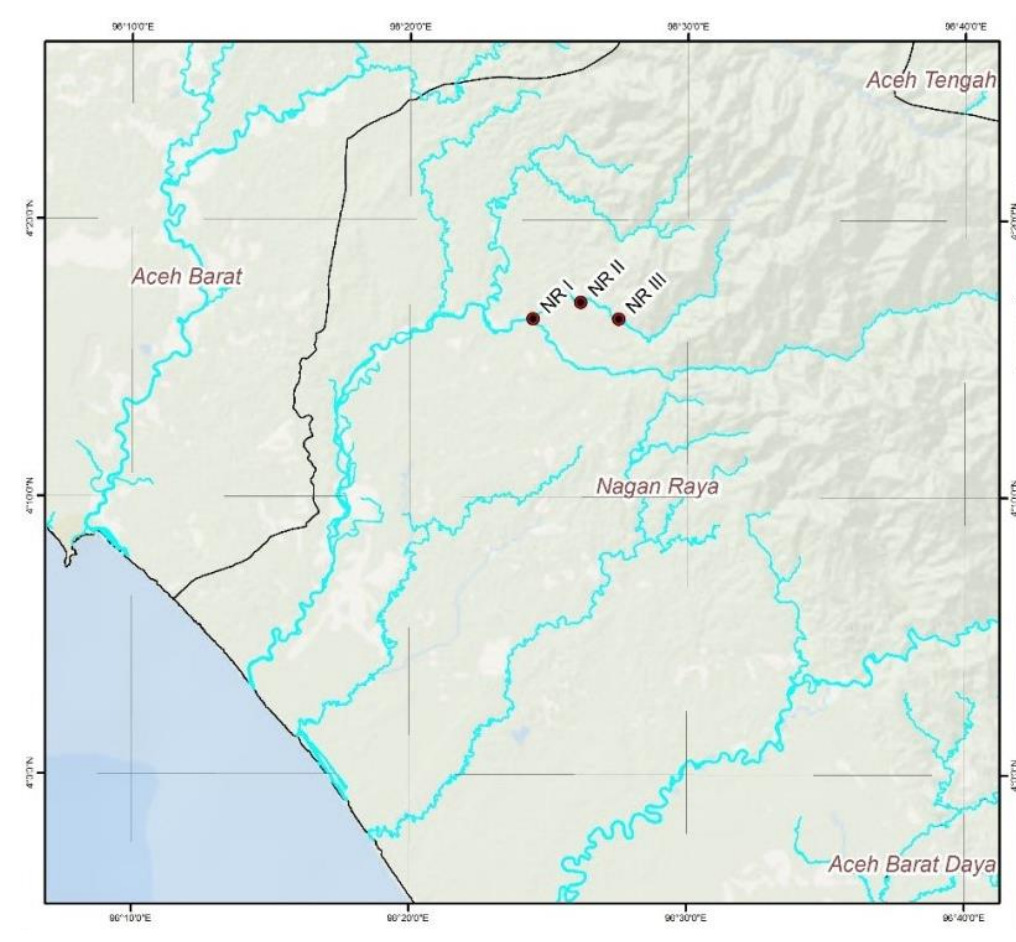

\section{RESEARCH MAP}
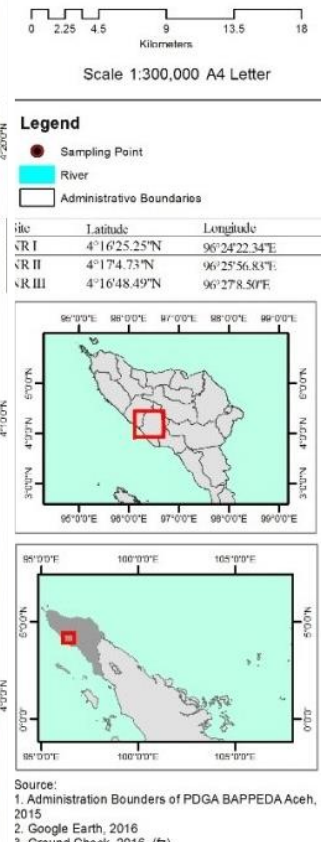

Figure 1. Map of Nagan Raya District, Aceh Province, Indonesia showing the sampling sites (black dots) 


\section{Sex dimorphism, sex ratio, and fecundity analyses}

Sex dimorphism was observed to distinguish the morphological and coloration differences between male and female fish. The sex ratio was calculated based on the work of Adenike (2013) and Muchlisin et al. (2010) as follows: Sex ratio $=$ Total male fish/Total female fish. The relative and total fecundities were examined using gravimetry following the work of Muchlisin et al. (2011) and Muchlisin (2014) as follows: $\mathrm{TF}=\mathrm{n} .\left(\mathrm{W}_{\mathrm{t}} / \mathrm{W}_{\mathrm{s}}\right) ; \mathrm{RF}=$ $\mathrm{TF} / \mathrm{BW}$, where TF is the total fecundity (oocytes per spawning season), $\mathrm{RF}$ is the relative fecundity (oocytes $\mathrm{g}^{-1}$ bodyweight), $\mathrm{n}$ is the total oocyte in a subsample of the gonad, Wt is the total weight of the gonad (g), Ws is the total weight of the subsample of the gonad $(\mathrm{g})$, and BW is the total body weight of fish (g).

\section{Histological analysis}

Histological samples were prepared based on the work of Muchlisin et al. (2010) as follows: the gonad samples were preserved with $10 \%$ formalin for 5 days. After one week, the gonad samples were washed with tap water and dehydrated in an increasing alcohol series (70\%-96\% alcohol) for $30 \mathrm{~min}$. Then, the gonad samples were cleared using xylene, embedded in paraffin, and then sectioned at 4-5 $\mu \mathrm{m}$ thickness using a microtome (SLEE Modelo CUT 4062). The sections were stretched in a $40^{\circ} \mathrm{C}$ water bath prepared with distilled water. The sections were mounted on an object-glass slide and then dried for $24 \mathrm{~h}$ at $37^{\circ} \mathrm{C}$ followed by one $\mathrm{h}$ drying at $60^{\circ} \mathrm{C}$ on a stove. The sections were stained with eosin for 15 min, dehydrated using $70 \%$ alcohol, and dried at $40^{\circ} \mathrm{C}$ for $25 \mathrm{~s}$. The samples were observed under a stereomicroscope (Olympus CX23, Japan).

\section{Ethics approval and consent to participate}

The authors confirm that the ethical policies of the journal have adhered to, and the study is in compliance with Syiah Kuala University Research and Ethics Guidelines, Section of Animal Care and Use in Research.
Chapter 6, Article 11-13 (https://lppm.unsyiah.ac.id/files/ Etika-Penelitian-Unsyiah.pdf).

\section{Data analysis}

The data are presented in tables and figures and were analyzed descriptively by comparison with relevant references and reports. In addition, we conducted statistical analysis (regression) on several research parameters including total length between fecundity and body weight between fecundity.

\section{RESULTS AND DISCUSSION}

\section{GSI and proportion of mature fish}

Compare to the males, the average GSI of female naleh fish was higher in January and April. The proportion of mature female fish was also higher during this month. The female GSI decreased during February and March, increased in April, and then decreased gradually from May to October (Table 1). The proportion of mature female fish also increased with the increase in GSI. Meanwhile, the high GSI values of male fish were observed in February, May, and June (Table 2). Matured fish were noted throughout the year, but higher proportions of matured females were recorded in January and April, whereas higher proportions of matured males were noted in February, May, and June. These findings indicated the asynchronous gonad maturation between male and female naleh fish where when the female GSI value was high, the male GSI value was low and vice versa. However, the synchronous gonad maturity was recorded in May and June. Based on the total length of fish samples, most of the matured female and male naleh fish reached sizes of 105125 and 83-103 mm, respectively. The females matured first at the size of $85 \mathrm{~mm}$, whereas males achieved maturity at a size of $73 \mathrm{~mm}$ (Figure 2).

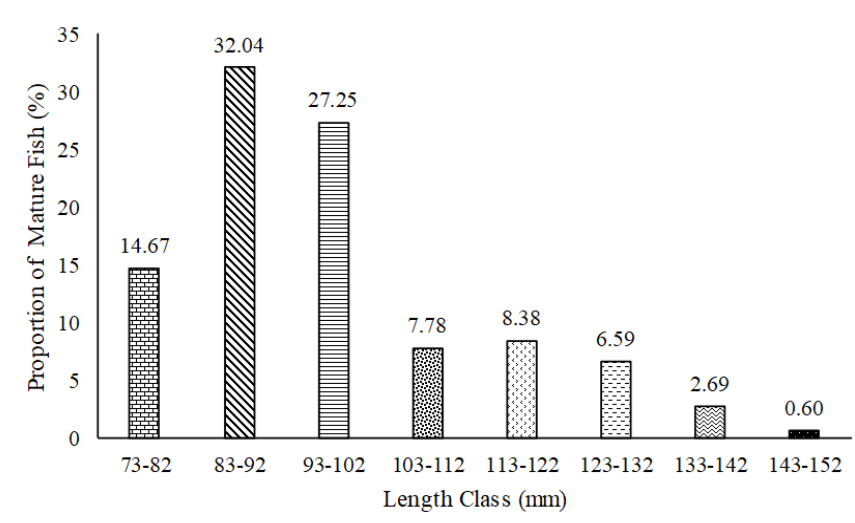

A

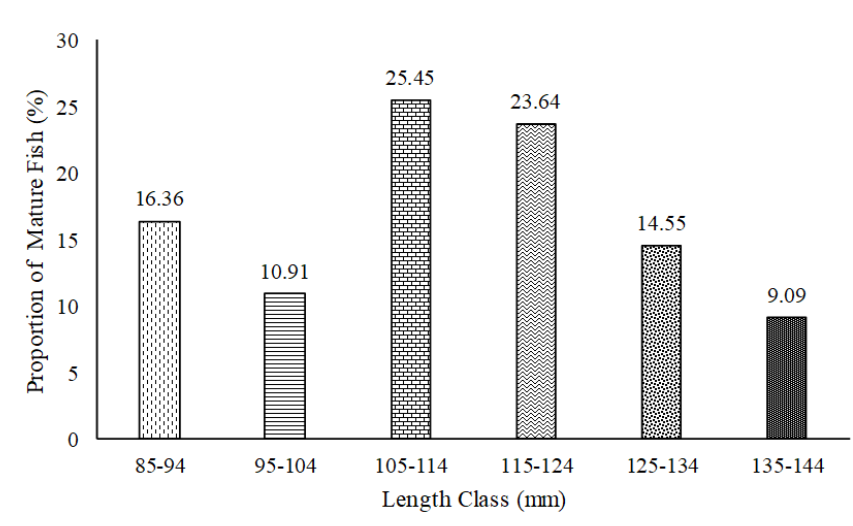

B

Figure 2. Proportion of mature fish based on length class for 12 months sampling: A. Male $(n=334$ fish); B. Female $(n=55$ fish) 
Table 1. Gonad development stage and GSI of Female naleh fish

\begin{tabular}{|c|c|c|c|c|c|c|c|c|c|c|}
\hline \multirow[t]{2}{*}{ Month } & \multirow{2}{*}{$\begin{array}{c}\text { Total } \\
\text { sample }\end{array}$} & \multicolumn{5}{|c|}{$\begin{array}{c}\text { Total fish based on gonad development stage } \\
(\%)\end{array}$} & \multirow[t]{2}{*}{ GSI (\%) } & \multicolumn{2}{|c|}{$\begin{array}{c}\text { Gonadal development } \\
(\%)\end{array}$} & \multirow{2}{*}{$\begin{array}{l}\text { Total } \\
-(\%)\end{array}$} \\
\hline & & I & II & III & IV & $\mathbf{V}$ & & Immature & Mature & \\
\hline January & 13 & 7.69 & 30.77 & 7.69 & $\mathbf{5 3 . 8 5}$ & 0.00 & $0.87-11.23(\mathbf{4 . 0 2} \pm \mathbf{3 . 0 0})$ & 38.46 & 61.54 & 100 \\
\hline February & 11 & 36.36 & 45.45 & 9.09 & 9.09 & 0.00 & $0.56-9.19(2.12 \pm 2.43)$ & 81.82 & 18.18 & 100 \\
\hline March & 6 & 0.00 & 16.67 & 16.67 & 33.33 & 33.33 & $0.87-3.77(1.97 \pm 1.08)$ & 50.00 & 50.00 & 100 \\
\hline April & 8 & 0.00 & 25.00 & 12.50 & 62.50 & 0.00 & $0.90-9.23(\mathbf{4 . 2 8} \pm \mathbf{3 . 0 9})$ & 25.00 & 75.00 & 100 \\
\hline May & 10 & 0.00 & 20.00 & 30.00 & 30.00 & 20.00 & $1.15-5.24(3.00 \pm 1.29)$ & 40.00 & 60.00 & 100 \\
\hline June & 7 & 28.57 & 14.29 & 57.14 & 0.00 & 0.00 & $0.86-5.20(3.15 \pm 1.93)$ & 42.86 & 57.14 & 100 \\
\hline July & 9 & 11.11 & 44.44 & 11.11 & 11.11 & 22.22 & $0.49-5.63(2.41 \pm 1.54)$ & 77.78 & 33.33 & 100 \\
\hline August & 15 & 53.33 & 26.67 & 6.67 & 13.33 & 0.00 & $0.20-7.05(2.48 \pm 2.17)$ & 80.00 & 20.00 & 100 \\
\hline September & 8 & 12.50 & $\mathbf{3 7 . 5 0}$ & 0.00 & 12.50 & $\mathbf{3 7 . 5 0}$ & $0.34-7.52(1.63 \pm 2.41)$ & 87.50 & 12.50 & 100 \\
\hline October & 4 & 25.00 & 25.00 & 25.00 & 0.00 & 25.00 & $0.19-1.54(0.58 \pm 0.63)$ & 75.00 & 25.00 & 100 \\
\hline November & 18 & 44.44 & 27.78 & 16.67 & 11.11 & 0.00 & $0.31-6.48(1.80 \pm 1.79)$ & 72.22 & 27.78 & 100 \\
\hline December & 26 & 26.92 & 19.23 & 42.31 & 11.54 & 0.00 & $0.56-6.22(2.37 \pm 1.66)$ & 46.15 & 53.85 & 100 \\
\hline
\end{tabular}

Noted: Bold value is the highest recorded in the respective month

Table 2. Gonad development stage and GSI of male naleh fish

\begin{tabular}{|c|c|c|c|c|c|c|c|c|c|c|}
\hline \multirow[t]{2}{*}{ Month } & \multirow{2}{*}{$\begin{array}{c}\text { Total } \\
\text { sample }\end{array}$} & \multicolumn{5}{|c|}{$\begin{array}{l}\text { Total fish based on gonad development stage } \\
(\%)\end{array}$} & \multirow[t]{2}{*}{ GSI (\%) } & \multicolumn{2}{|c|}{$\begin{array}{c}\text { Gonadal development } \\
(\%)\end{array}$} & \multirow{2}{*}{$\begin{array}{c}\text { Total } \\
(\%)\end{array}$} \\
\hline & & I & II & III & IV & $\mathbf{V}$ & & Immature & Mature & \\
\hline January & 70 & 15.71 & 25.71 & 27.14 & 31.43 & 0.00 & $0.31-5.95(2.25 \pm 1.29)$ & 41.43 & $\mathbf{5 8 . 5 7}$ & 100 \\
\hline February & 54 & 3.70 & 11.11 & 27.78 & 55.56 & 1.85 & $0.68-8.47(4.18 \pm \mathbf{1 . 9 5})$ & 16.67 & 83.33 & 100 \\
\hline March & 51 & 15.69 & 19.61 & 21.57 & 37.25 & 5.88 & $0.20-6.74(2.56 \pm 1.66)$ & 41.18 & 58.82 & 100 \\
\hline April & 75 & 40.00 & 12.00 & 10.67 & 37.33 & 0.00 & $0.10-7.63(2.19 \pm 1.98)$ & 52.00 & 48.00 & 100 \\
\hline May & 57 & 0.00 & 38.60 & 33.33 & 26.32 & 1.75 & $0.63-10.53(\mathbf{3 . 0 1} \pm \mathbf{1 . 6 2})$ & 40.35 & 59.65 & 100 \\
\hline June & 52 & 13.46 & 15.38 & 19.23 & 51.92 & 0.00 & $0.44-5.54(\mathbf{3 . 1 5} \pm \mathbf{1 . 4 0})$ & 28.85 & 71.15 & 100 \\
\hline July & 52 & 26.92 & 21.15 & 7.69 & 38.46 & 5.77 & $0.17-14.71(2.91 \pm 2.74)$ & 53.85 & 46.15 & 100 \\
\hline August & 51 & 29.41 & 19.61 & 11.76 & 39.22 & 0.00 & $0.41-7.52(2.71 \pm 1.92)$ & 49.02 & 50.98 & 100 \\
\hline September & 43 & 18.60 & 39.53 & 18.60 & 20.93 & 2.33 & $0.17-10.04(1.85 \pm 1.68)$ & 60.47 & 39.53 & 100 \\
\hline October & 56 & 21.43 & 26.79 & 17.86 & 19.64 & 14.29 & $0.12-9.04(1.24 \pm 1.57)$ & 62.50 & 37.50 & 100 \\
\hline November & 39 & 38.46 & 30.77 & 23.08 & 7.69 & 0.00 & $0.14-4.57(1.44 \pm 1.00)$ & 69.23 & 30.77 & 100 \\
\hline December & 26 & 38.46 & 19.23 & 11.54 & 30.77 & 0.00 & $0.43-3.74(1.59 \pm 0.88)$ & 57.69 & 42.31 & 100 \\
\hline
\end{tabular}

Note: Bold value is the highest recorded in the respective month

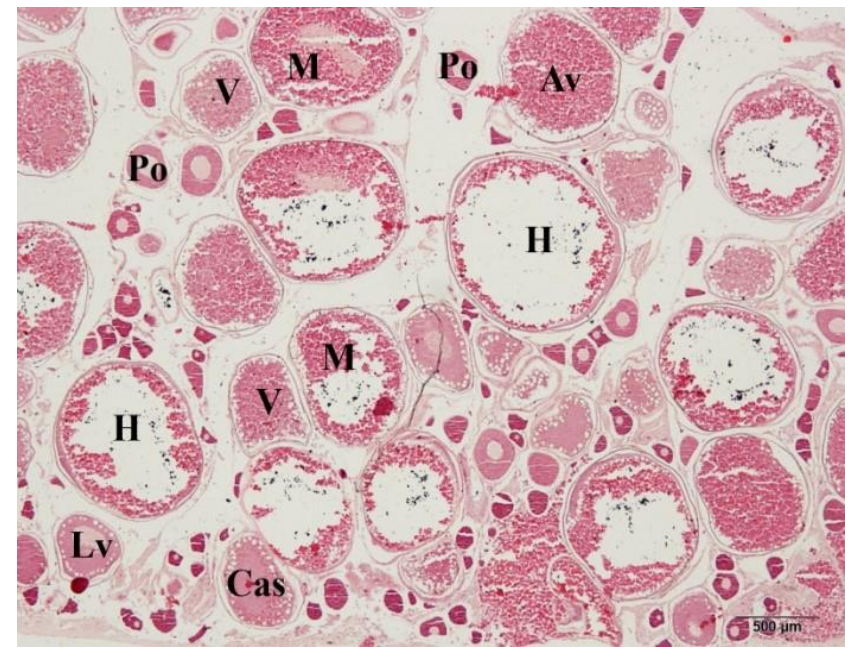

Figure 3. Asynchronous maturity of naleh gonad: primary oocytes (Po), lipid vesicles (Lv), cortical alveolus stage (Cas), vitellogenic $(\mathrm{V})$; advanced vitellogenic $(\mathrm{Av})$, migrating $(\mathrm{M})$, and hydrated (H) stages
Histological analysis of female gonads (ovary) showed that the gonads consisted of oocytes of several sizes, indicating that the fish exhibited asynchronous gonad development (Figure 3). This study revealed seven stages of gonad development among the female naleh fish, namely: primary oocytes with an average size of $\pm 50 \mu \mathrm{m}$, lipid vesicle stage (average oocyte size of $\pm 275 \mu \mathrm{m}$ ), cortical alveolus stage (average oocyte size of $\pm 385 \mu \mathrm{m}$ ), vitellogenic stage (average oocyte size of $\pm 650 \mu \mathrm{m}$ ), protein granule stage (average oocyte size of $\pm 750 \mu \mathrm{m}$ ), migrating stage with the oocyte size of $\pm 1000 \mu \mathrm{m}$, and migrating stage with the oocyte size of $\pm 1250 \mu \mathrm{m}$ (Figure 4). No significant correlation was observed between GSI and rainfall in 2016 (Figure 5).

\section{Sex ratio, fecundity, and dimorphism}

The results revealed that the male naleh fish was predominant throughout the year with the highest ratio in October, whereas the sex ratios of males and females were equal in December (Table 3). The total fecundity ranged between 656-5725 eggs with an average of 2663 eggs per 
spawning season, whereas the relative fecundity ranged between 36-255 eggs g-1 bodyweight with an average of 137 eggs g $^{-1}$ bodyweight. A strong relationship was noted between fecundity and body weight, that is, fecundity increased with the increase in body weight (Figure 6.A). A similar trend was also observed in the fish length, that is, the fecundity increased as the total length increased. For example, the fish with a length between $85 \mathrm{~mm}$ to $95 \mathrm{~mm}$ yielded 1110.8 eggs per fish, and it increased to 4552.5 eggs at lengths between $135 \mathrm{~mm}$ to $145 \mathrm{~mm}$ (Figure 6.B). Male and female fish showed sexual dimorphism, in which the male fish are smaller than females. The male naleh fish showed a compressed body shape, whereas the females exhibited a unanimous body shape. However, the sex coloration between male and female was difficult to distinguish.
Table 3. Sex ratio of Barbonymus sp. according to monthly sampling

\begin{tabular}{lccccc}
\hline \multirow{2}{*}{ Month } & \multicolumn{2}{c}{ Total individuals } & \multicolumn{2}{c}{ Proportion $(\%)$} & Ratio \\
\cline { 2 - 5 } & Male & Female & Male & Female & (M: F) \\
\hline January & 70 & 13 & 84.34 & 15.66 & 5.4 \\
February & 54 & 11 & 83.08 & 16.92 & 4.9 \\
March & 51 & 6 & 89.47 & 10.53 & 8.5 \\
April & 75 & 8 & 90.36 & 9.64 & 9.4 \\
May & 57 & 10 & 85.07 & 14.93 & 5.7 \\
June & 52 & 7 & 88.14 & 11.86 & 7.4 \\
July & 52 & 9 & 85.25 & 14.75 & 5.8 \\
August & 51 & 15 & 77.27 & 22.73 & 3.4 \\
September & 43 & 8 & 84.31 & 15.69 & 5.4 \\
October & 56 & 4 & 93.33 & 6.67 & 14.0 \\
November & 39 & 18 & 68.42 & 31.58 & 2.2 \\
December & 26 & 26 & 50.00 & 50.00 & 1.0 \\
Average & 52.17 & 11.25 & 81.59 & 18.41 & 6.1 \\
\hline
\end{tabular}

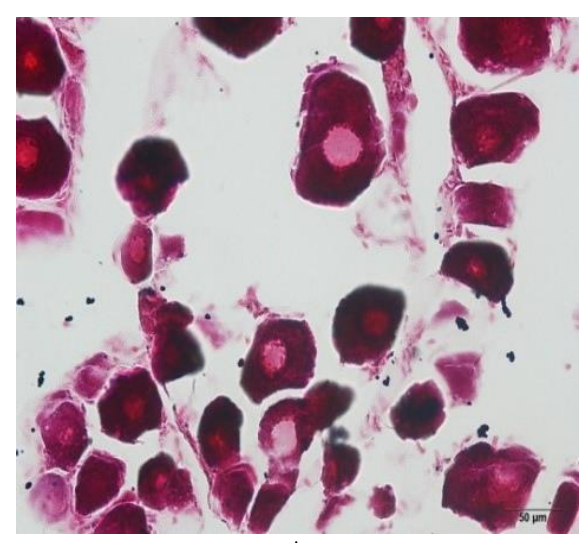

A

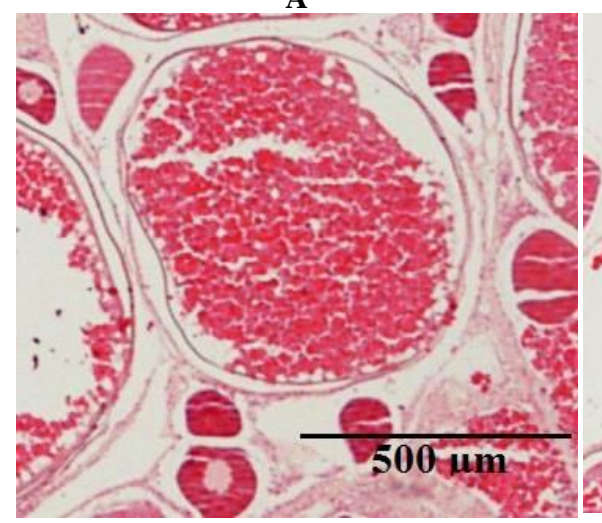

D

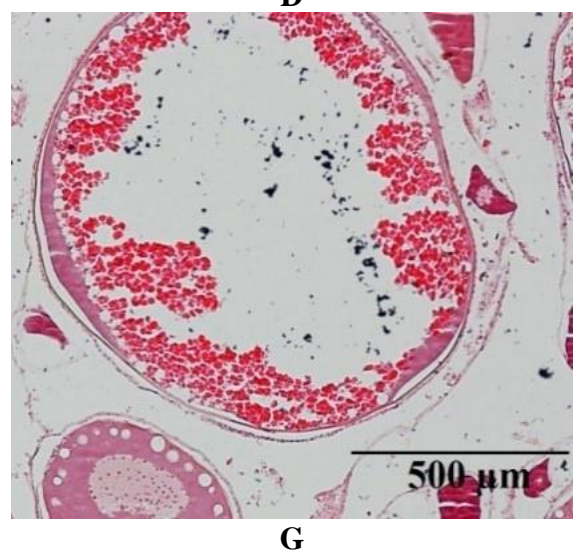

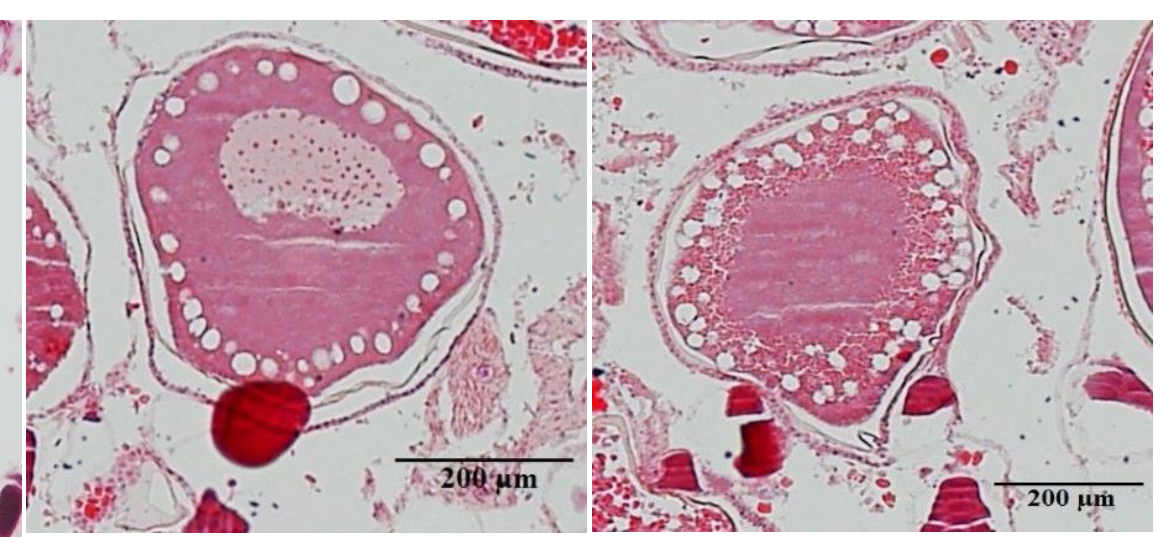

B

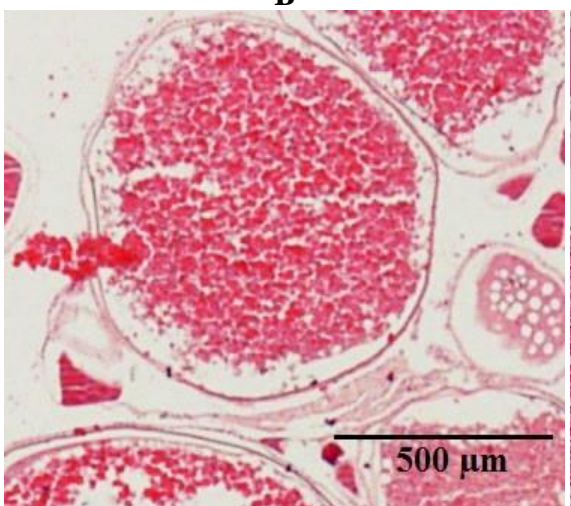

E

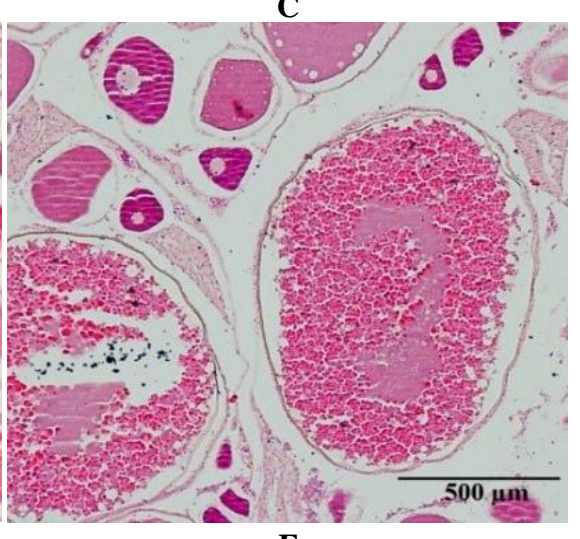

$\mathbf{F}$

Figure 4. Gonad development of female fish based on oocyte size: A. Primary oocyte; B. Lipid vesicle; C. Cortical alveolus stage; D. Vitellogenic; E. Advanced vitellogenic; F. Migrating; G. Hydrated stages 


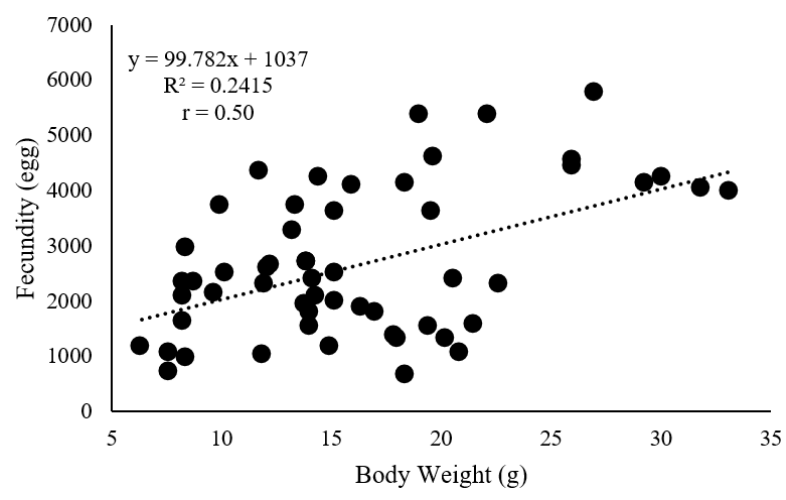

A

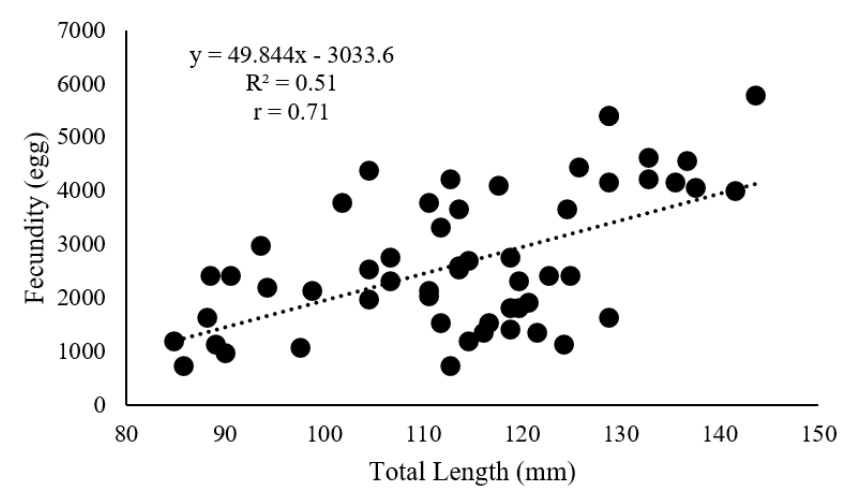

B

Figure 6. A. correlation between body weight and fecundity and B. the correlation between total length and fecundity

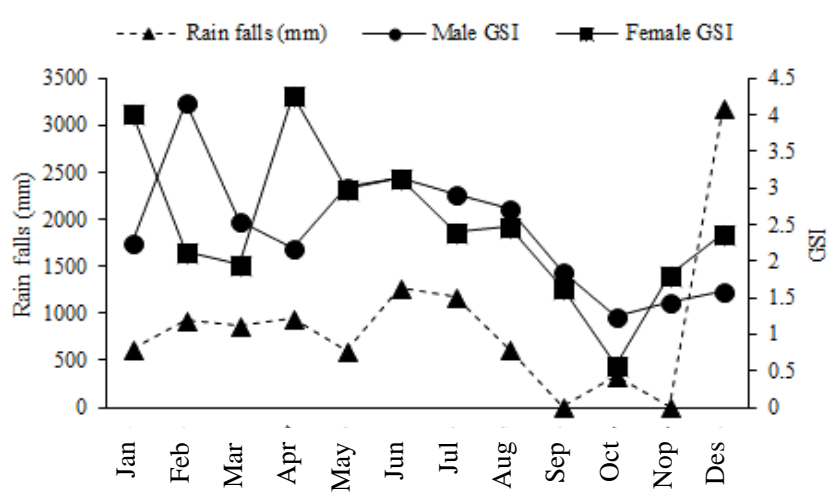

Figure 5. Relationship between rainfall and average GSI of naleh fish in 2016

The study revealed that naleh fish Barbonymus sp. are multiple spawners, that is, they spawn over a year with the peak of spawning season in May and June or at the end of the rainy season. Histological analysis showed several sizes of oocytes in the ovary, indicating the asynchronous gonad development pattern. Asynchronous multiple spawners were also recorded for B. schwanenfeldii from Perak River, Malaysia (McAdam et al. 1999). However, a contrary finding was reported for the B. gonionotus from Rajshahi waters Bangladesh (Bhuiyan et al. 2006) and from Serayu river Central Java, Indonesia (Haryono et al. 2015), where this species thrives as a total spawner. According to the work of Colmenero et al. (2013), a gonad of total spawner fish had oocytes with a homogenous size, indicating the same level of development (synchronous); these fish can lay eggs as a whole during spawning, whereas multiple spawner fish feature different levels of oocyte development (asynchronous) in the gonad, which consists of several oocyte sizes that indicate different levels of maturity; thus, at the time of spawning, the eggs released are only those that have matured, whereas the unmatured ones will be released in the next (Muchlisin 2014). Haryono et al. (2015) reported that spawning patterns in fish are influenced by the availability of food sources, water temperatures (seasons), and locations; therefore, fish of the same species but different locations possibly have different spawning patterns as detected in this study. However, no correlation was detected between rainfall and the spawning season of naleh fish. However, in general, the peak spawning season of freshwater fish in tropical region occurs during the rainy season as recorded in several species, including depik Rasbora tawarensis in Lake Laut Tawar, Indonesia (Muchlisin et al. 2010, 2011), Prochilodus brevis in the Brazilian (Chellappa et al. 2009), and $R$. lateristriata in Ngrancah River, Indonesia (Sentosa et al. 2010).

The present study revealed that the Barbonymus sp. males first mature at $73 \mathrm{~mm}$ followed by the females at a size of $85 \mathrm{~mm}$, with the total fecundity reaching 2663 eggs. These sizes are smaller than those of other Barbonymus, for example, Jasmine and Begum (2016) reported that the $B$. gonionotus females in Padma waters, Bangladesh first show mature gonads at $130 \mathrm{~mm}$ size, with the mean total fecundity reaching 58,660 eggs. Moreover, Bhuiyan et al. (2006) reported that the female B. gonionotus from Rajshahi waters, Bangladesh first mature at $159 \mathrm{~mm}$ in size with an average fecundity of 6964 eggs. Besides, female $B$. balleroides first mature at a size of $175 \mathrm{~mm}$, with a total fecundity of 17,347 eggs (Haryono et al. 2015). The size of the first mature fish gonad is an important indication of overfishing, where overfished species tend to mature earlier or at smaller sizes. Therefore, based on this present study and data on population dynamics (Batubara et al. 2019b), the naleh fish in the Nagan Raya River has been overfished, and this previous finding is supported by the present study. A similar finding was observed with Rasbora tawarensis (locally name of depik), another endemic species of fish in Aceh (Muchlisin et al. 2010).

The results showed that the fecundity of naleh fish was positively correlated with body weight and the total length, where the fecundity increased with increasing fish length and body weight. This finding coincides with that of Bhuiyan et al. (2006), who worked on B. gonionotus. A similar finding was also reported for $R$. tawarensis in Lake Laut Tawar (Muchlisin et al. 2010) and Scaphirhynchus albus and Noturus placidus (Bulger et al. 2002; Albers et 
al. 2013). In general, the fecundity of naleh fish is lower than other Barbonymus species, for example, B. gonionotus in the Padma waters (Jasmine and Begum 2016) and Rajshahi waters Bangladesh (Bhuiyan et al. 2006), $B$. schwanenfeldii in Jambi waters (Kusmini et al. 2018) and the Iberian Peninsula (Gante et al. 2008), and $B$. collingwoodii in Opak River, Bantul, Jogjayakarta (Yusuf 2013). However, the fecundity of naleh fish is higher than that of B. balleroides in Cirata Reservoir, Cianjur, West Java (Kusmini et al. 2017b). Bryan et al. (2007) stated that fecundity is not only influenced by internal factors (genetics, age, and size) but also by external factors, including feed sources and environmental conditions. Therefore, fish of the same species but different water habitats will possibly have varying fecundities due to environmental conditions and the availability of food sources.

The sex ratio of naleh fish shows that males were predominant with a ratio of 1:4 (female: male), whereas the mature fish sex ratio was 1:6 (female: male). The ideal sex ratio is when the numbers of males and females are balanced (Haryono et al. 2015; Jasmine and Begum 2016). Baroiller et al. (2008) indicated that the sex ratio of fish in nature is strongly influenced by the temperature and $\mathrm{pH}$ of the waters, for instance, in tilapia, warmer waters will produce more male fish. This condition is probably related to global warming, where the average earth temperature has been increasing over the years (Levitus et al. 2000; King et al. 2006). The low number of females will have an impact on the low number of new recruitments of progeny; on the other hand, the threat to the naleh fish population in the Nagan river has been increasing over years due to overfishing, environmental damage, and pollution (Batubara et al. 2019b). Besides, mature female fish are mainly targeted by local fishermen because the eggs are popularly consumed by the locals. This practice is probably another reason why the number of female fish is lower. Besides, based on the observations in the present study, in the dry season (or at the end of the rainy season), which is also the peak of the spawning season of this species, local fishermen use poison to catch fish. This condition gives pressure on the naleh fish population in the Nagan river.

In conclusion, naleh fish are asynchronous multiple spawners; they spawn throughout the year with the spawning season peak in May and June. The males are predominant in the population with the sex ratio male: female was 6.1. The male fish first mature at $73 \mathrm{~mm}$, followed by females at $85 \mathrm{~mm}$, with the average total and relative fecundities of 2663 eggs and $136.88 \mathrm{eggs}_{\mathrm{gram}}{ }^{-1}$ body weight, respectively.

\section{ACKNOWLEDGEMENTS}

The authors thank the Ichthyofaunas Research Group members for their kind cooperation during laboratory work and Khaidir for his assistance during the field survey.

\section{REFERENCES}

Abdullah A, Ramly R, Ridzwan MSM, Sudirwan F, Abas A, Ahmad K, Murni M, Kua BC. 2018. First detection of tilapia lake virus (TiLV) in wild river carp (Barbonymus schwanenfeldii) at Timah Tasoh Lake, Malaysia. J Fish Dis 41: 1459-1462. DOI: 10.1111/jfd.12843.

Adenike FA. 2013. The sex ratio, gonadosomatic index, stages of gonadal development and fecundity of Sompat Grunt, Pomadasys jubelini (Cuvier, 1830). Pak J Zool 45 (1): 41-46.

Albers JL, Wildhaber ML, De-Lonay AJ. 2013. Gonadosomatic index and fecundity of Lower Missouri and Middle Mississippi River endangered pallid sturgeon estimated using minimally invasive techniques. J Appl Ichthyol 29: 1-10. DOI: 10.1111/jai.12231.

Apendi A, Ling TY, Nyanti L, Sim SF, Grinang J, Ganyai T. 2018. Tolerance of Barbonymus schwanenfeldii under sulfide exposure. AACL Bioflux 11 (5): 1574-1586.

Barbieri SKL, Peterson NJB, Murua H, Tomkiewicz J, Wyaski DM, Saborido-rey F. 2011. Emerging issues and methodological advances in fisheries reproductive biology. Mar Coast Fish 3: 32-51. DOI: 10.1080/19425120.2011.555725.

Baroiller JF, D'Cotta H, Saillant E. 2008. Environmental effects on fish sex determination and differentiation. Sex Dev 3: 118-135. DOI: 10.1159/000223077.

Batubara AS, Muchlisin ZA, Efizon D, Elvyra R, Fadli N, Irham M. 2018. Morphometric variations of the Genus Barbonymus (Pisces, Cyprinidae) harvested from Aceh Waters, Indonesia. Fish Aquat Life 26: 231-237. DOI: 10.2478/aopf-2018-0026.

Batubara AS, Muchlisin ZA, Efizon D, Elvyra R, Irham M. 2019a. Length-weight relationships and condition factors of the naleh fish, Barbonymus gonionotus (Pisces, Cyprinidae) harvested from Nagan Raya Waters, Indonesia. Vestnik Zool 53: 75-82. DOI: 10.2478/vzoo2019-0008.

Batubara AS, Efizon D, Elvyra R, Rizal S, Muchlisin ZA. 2019 b. Population dynamics of the naleh fish Barbonymus sp. (Pisces: Cyprinidae) in Nagan River Waters, Aceh Province, Indonesia. Jordan J Biol Sci 12 (3): 361-366.

Bhuiyan AS, Islam K, Zaman T. 2006. Fecundity and ovarian characteristics of Puntius gonionotus (Bloch/Bleeker) (Cyprinidae: Cypriniformes). J Bio-sci 4: 99-102. DOI: 10.3329/jbs.v14i0.451.

Bryan JL, Wildhaber ML, Papoulias DM, De-Lonay AJ, Tillitt DE, Annis ML. 2007. Estimation of gonad volume, fecundity, and reproductive stage of shovelnose sturgeon using sonography and endoscopy with application to the endangered pallid sturgeon. J Appl Ichthyol 23: 411-419. DOI: 10.1111/j.1439-0426.2007.00889.x.

Bulger AG, Wilkinson CD, Edds DR. 2002. Breeding behavior and reproductive life history of the Neosho Madtom, Noturus placidus (Teleostei: Ictaluridae). Transact Kansas Acad Sci 105: 106-124. DOI: 10.1660/0022-8443(2002)105[0106:bbarlh]2.0.co;2.

Chellappa S, Bueno RMX, Chellappa T, Chellappa NT, Eval VMFA. 2009. Reproductive seasonality of the fish fauna and limnoecology of semi-arid Brazilian reservoirs. Limnologica 39: 325-329. DOI: 10.1016/j.limno.2009.06.003.

Cheng P, Baran E, Touch BT. 2004. Synthesis of All Published Information on Java Barb Barbonymus gonionotus ("trey chopin") based on Fishbase 2004. WorldFish Center and Inland Fisheries Research and Development Institute, Cambodia.

Chew PC, Zulkafli AR. 2012. Sperm Cryopreservation of Some Freshwater Fish Species in Malaysia. InTech Published, China.

Cnaani A, Sivan BL. 2009. Sexual development in fish, practical applications for aquaculture. Sex Dev 3: 164-175. DOI: 10.1159/000223080.

Colmenero AI, Tuset VM, Recasens L, Sanchez P. 2013. Reproductive biology of black anglerfish (Lophius budegassa) in the northwestern Mediterranean Sea. Fish Bull 111: 390-401. DOI: 10.7755/fb.111.4.8.

Dewantoro E. 2015. Keragaan gonad ikan tengadak (Barbonymus schwanenfeldii) setelah diinjeksi hormon HCG secara berkala. Jurnal Akuatika 6 (1): 1-10. [Indonesian]

Eslamloo K, Morshedi V, Azodi M, Ashouri G, Ali M, Iqbal F. 2012. Effects of starvation and re-feeding on growth performance, feed utilization and body composition of Tinfoil barb (Barbonymus schwanenfeldii). World J Fish Mar Sci 4: 489-495. DOI: 10.5829/idosi.wjfms.2012.04.05.6465.

Eslamloo K, Akhavan SR, Henry MA. 2013. Effects of dietary administration of Bacillus probiotics on the non-specific immune responses of tinfoil barb, Barbonymus schwanenfeldii 
(Actinopterygii: Cypriniformes: Cyprinidae). Acta Ichthyol Piscatoria 43: 211-218. DOI: 10.3750/aip2013.43.3.05.

Eslamloo K, Morshedi V, Azodi M, Akhavan SR. 2017. Effect of starvation on some immunological and biochemical parameters in tinfoil barb (Barbonymus schwanenfeldii). J Appl Anim Res 45: 173178. DOI: $10.1080 / 09712119.2015 .1124329$.

Froese R, Pauly D. 2018. Fishbase, Genus Barbonymus. http://www.fishbase.org/Nomenclature/ScientificNameSearchList.php $?$.

Gante HF, Moreira LDC, Micael J, Alves MJ. 2008. First record of Barbonymus schwanenfeldii (Bleeker) in the Iberian Peninsula. J Fish Biol 72: 1089-1094. DOI: 10.1111/j.1095-8649.2007.01773.x.

Haryono H, Rahardjo MF, Affandi R, Mulyadi M. 2015. Reproductive biology of barb fish (Barbonymus balleroides, Val. 1842) in fragmented habitat of upstream Serayu River Central Java, Indonesia. Intl J Sci Basic Appl Res 23 (1): 189-200.

Hossain MY, Hossen MA, Islam MM, Pramanik MNU, Nawer F, Paul AK, Hameed HMA, Rahman MM, Kaushik G, Bardoloi S. 2016 Biometric indices and size at first sexual maturity of eight alien fish species from Bangladesh. Egyptian J Aqua Res 42: 331-339. DOI: 10.1016/j.ejar.2016.09.001.

Hossen B, Hossain MS, Rashid I, Hasan MN, Ethin R, Thapa H, Majumdar BC. 2017. Effect of extenders and storage periods on motility and fertilization rate of silver barb, Barbonymus gonionotus (Bleeker, 1850) semen. Intl J Agric Pol Res 5: 178-185. DOI: 10.15739/IJAPR.17.021

Huwoyon GH, Kusmini II. 2017. Pertumbuhan ikan tengadak albino dan hitam (Barbonymus schwanenfeldii) dalam kolam. Jurnal Iktiologi Indonesia 10 (1): 47-54. DOI: 10.32491/jii.v10i1.177. [Indonesian]

Huwoyon GH, Kusmini II, Kristanto AH. 2018. Keragaan pertumbuhan ikan tengadak alam (hitam) dan tengadak budidaya (merah) (Barbonymus schwanenfeldii) dalam pemeliharaan bersama pada kolam beton. Prosiding Forum Inovasi Teknologi Akuakultur 1: 501505. [Indonesian]

Idris M, Noor NM, Das SK. 2017. Growth performance of tinfoil barb (Barbonymus schwanenfeldii) fry feeding with different protein content diets. AACL Bioflux 10 (3): 475-479.

Isa MM, Shahrul-Anuar ASMS, Muhammad-Adlan MSNB. 2012 Population dynamics of tinfoil barb, Barbonymus schwanenfeldii (Bleeker, 1853) in Pedu Reservoir, Kedah. J Biol Agric Healthc 2 (5) 55-69.

Jasmine S, Begum M. 2016. Biological aspects of Barbonymus gonionotus (Bleeker, 1849) in the Padma River, Bangladesh. Intl J Fish Aqua Stud 4 (5): 661-665.

Kamarudin KR, Esa Y. 2009. Phylogeny and phylogeography of Barbonymus schwanenfeldii (Cyprinidae) from Malaysia inferred using partial cytochrome $b$ mtDNA gene. J Trop Biol Conserv 5: 113.

King AW, Gunderson CA, Post WM, Weston DJ, Wullschleger SD. 2006 Plant respiration in a warmer world. Science 312: 536-537. DOI: $10.1126 /$ science. 1114166.

Kottelat M. 2001. Fishes of Laos. WHT Publications (Pte), Colombo.

Kusmini II, Gustiano R, Radona D, Prakoso VA, Putri FP, Prihadi TH 2017a. Karakterisasi fenotipe dan genotipe tiga populasi ikan tengadak (Barbonymus schwanenfeldii). Jurnal Riset Akuakultur 11 (3): 207-216. DOI: 10.15578/jra.11.3.2016.207-216. [Indonesian]

Kusmini II, Putri FP, Prakoso VA. 2017b. Bioreproduksi dan hubungan panjang-bobot terhadap fekunditas pada ikan lalawak (Barbonymus balleroides). Jurnal Riset Akuakultur 11 (4): 339-345. DOI 10.15578/jra.11.4.2016.339-345. [Indonesian]

Kusmini II, Subagja J, Putri FP. 2018. Hubungan panjang dan berat, faktor kondisi, fekunditas, dan perkembangan telur ikan tengadak (Barbonymus schwanenfeldii) dari Sarolangun, Jambi Dan Anjongan, Kalimantan Barat, Indonesia. Berita Biologi 17 (2): 195-203. DOI: 10.14203/beritabiologi.v17i2.3017 [Indonesian]

Leunda PM. 2010. Impacts of non-native fishes on Iberian freshwate ichthyofauna: current knowledge and gaps. Aquat Invasion 5: 239262. DOI: 10.3391/ai.2010.5.3.03

Levitus S, Antonov JI, Boyer TP, Stephens C. 2000. Warming of the world ocean. Science 287: 2225-2229. DOI: 10.1126/science.287.5461.2225.

McAdam DSO, Liley NR, Tan ESP. 1999. Comparison of reproductive indicators and analysis of the reproductive seasonality of the tinfoil barb, Puntius schwanenfeldii, in the Perak River, Malaysia. Environ Biol Fish 55: 369-380. DOI: 10.1023/a:1007563914300.
Mollah MFA, Moniruzzaman M, Rahman MM. 2011. Effects of stocking densities on growth and survival of Thai Sharpunti (Barbonymus gonionotus) in earthen ponds. J Bangladesh Agric Univ 9: 327-338. DOI: $10.3329 /$ jbau.v9i2.11048.

Mondol MR, Dewan S, Hossain MA, Asaduzzaman M, Islam MA, Rozario UA. 2005. Food and feeding habits of Puntius gonionotus (Thai Sarpunti) in rice field. Pak J Biol Sci 8: 386-395. DOI: 10.3923/pjbs.2005.386.395.

Muchlisin ZA, Siti-Azizah MN. 2009. Diversity and distribution of freshwater fishes in Aceh Waters, Northern Sumatera, Indonesia. Intl J Zool Res 5: 62-79. DOI: 10.3923/ijzr.2009.62.79.

Muchlisin ZA, Musman M, Siti Azizah MN. 2010. Spawning seasons of Rasbora tawarensis in Lake Laut Tawar, Aceh Province, Indonesia. Reprod Biol Endocrinol 8: 1-8. DOI: 10.1186/1477-7827-8-49.

Muchlisin ZA, Musman M, Fadli N, Siti-Azizah MN. 2011. Fecundity and spawning frequency of Rasbora tawarensis (Pisces: Cyprinidae) an endemic species from Lake Laut Tawar, Aceh, Indonesia. AACL Bioflux 4: 273-279.

Muchlisin ZA. 2013. Potency of freshwater fishes in Aceh waters as a basis for aquaculture development programs. Jurnal Iktiologi Indonesia 13 (1): 91-96. DOI: 10.32491/jii.v13i1.115.

Muchlisin ZA. 2014. A general overview on some aspects of fish reproduction. Aceh Intl J Sci Technol 3: 43-52. DOI: 10.13170/aijst.3.1.1355

Muchlisin ZA, Akyun Q, Rizka S, Fadli N, Sugianto S, Halim A, SitiAzizah MN. 2015. Ichthyofauna of Tripa Peat Swamp Forest, Provinsi Aceh, Indonesia. Check List 11: 1-9. DOI: 10.15560/11.2.1560.

Nyanti L, Ling TY, Soo CL, Sim SF, Grinang J. 2017. Acidification tolerance of Barbonymus schwanenfeldii (Bleeker, 1854) and Oreochromis niloticus (Linnaeus, 1758)-implication of fish size. AACL Bioflux 10: 746-753.

Nyanti L, Soo CL, Ahmad-Tarmizi NN, Ling TY, Sim SF, Grinang J, Ganyai T, Ping LS. 2018. Effects of water temperature, dissolved oxygen and total suspended solids on juvenile Barbonymus schwanenfeldii (Bleeker, 1854) and Oreochromis niloticus (Linnaeus, 1758). AACL Bioflux 11: 394-406.

Radona D, Soelistyowati DT, Carman O, Gustiano R. 2017. Keragaman genotipe dan morfometrik ikan tengadak Barbonymus schwanenfeldii (Bleeker 1854) asal Sumatera, Jawa, dan Kalimantan. Jurnal Iktiologi Indonesia 16 (3): 259-268. [Indonesian]

Sabarudin N, Idris NSU, Halim NSA. 2017. Determination of condition factor (CF) and hepatosomatic index (HSI) of Barbonymus schwanenfeldii from Galas River, Kelantan. J Trop Resour Sustain Sci 5: 55-57.

Satrawaha R, Pilasamorn C. 2009. Length-weight and length-length relationships of fish species from the Chi River, northeastern Thailand. J Appl Ichthyol 25: 787-788. DOI: 10.1111/j.14390426.2009.01293.x.

Sentosa AA, Djumanto D. 2010. Spawning habitat of Rasbora lateristriata in Ngrancah River, Kulon Progo Regency. Jurnal Iktiologi Indonesia 10: 55-63. DOI: 10.32491/jii.v10i1.178.

Song B, Lin X, Xu Z. 2012. Effects of upstream exercise training on feeding efficiency, growth and nutritional components of juvenile tinfoil barbs (Barbodes schwanenfeldi). J Fish China 36: 106-114. DOI: $10.3724 /$ sp.j.1231.2012.27597.

Székely CS, Shaharom-harrison F, Cech G, Ostoros G, Molnár K. 2009. Myxozoan infections in fishes of the Tasik Kenyir water reservoir, Terengganu, Malaysia. Dis Aquat Org 83: 37-48. DOI: 10.3354/dao01991.

Yang L, Hirt V, Sado T, Arunachalam M, Manickam R, Tang KL, Simons AM, Wu H, Mayden RL, Miya M. 2012. Phylogenetic placements of the barbin genera Discherodontus, Chagunius, and Hypselobarbus in the subfamily Cyprininae (Teleostei: Cypriniformes) and their relationships with other barbins. Zootaxa 3586: 26-40. DOI: 10.11646/zootaxa.3586.1.5.

Yusuf IF. 2013. Biologi Reproduksi Ikan Kepek (Barbonymus collingwoodii) di Sungai Opak Kabupaten Bantul. [Dissertation]. Universitas Gadjah Mada, Yogyakarta. [Indonesian]

Zheng LP, Yang JX, Chen XY. 2016. Molecular phylogeny and systematics of the Barbinae (Teleostei: Cyprinidae) in China inferred from mitochondrial DNA sequences. Biochem Syst Ecol 68: 250-259. DOI: 10.1016/j.bse.2016.07.012.

Zhu Z, Song B, Lin X, Xu Z. 2016. Effect of sustained training on glycolysis and fatty acids oxidation in swimming muscles and liver in juvenile tinfoil barb Barbonymus schwanenfeldii (Bleeker, 
1854). Fish Physiol Biochem 42: 1807-1817. DOI: 10.1007/s10695- 016-0259-6. 